\title{
Southwestern Gondwana's Permian climate amelioration recorded in coal-bearing deposits of the Moatize sub-basin (Mozambique)
}

\author{
Annette E. Götz ${ }^{\text {a, b } * \text {, P. John Hancox }}{ }^{\text {c }}$, Andrew Lloyd ${ }^{\mathrm{d}}$
}

${ }^{a}$ University of Portsmouth, School of Earth and Environmental Sciences, Portsmouth, PO1 3QL, United Kingdom

b Kazan Federal University, 18 Kremlyovskaya Street, Kazan 420008, Republic of Tatarstan, Russian Federation

c University of the Witwatersrand, School of Geosciences and Evolutionary Studies Institute, Private Bag 3, 2050 Wits, South Africa

${ }^{\mathrm{d}}$ Consulting Geologist, Johannesburg, South Africa

* Corresponding author. E-mail address: annette.goetz@port.ac.uk

\begin{abstract}
The postglacial climate history of Gondwana represents the most prominent climate amelioration in the Phanerozoic, ranging from severe icehouse conditions in the Late Carboniferous (Pennsylvanian) to extreme hothouse conditions in the Early Triassic. Here we report new sedimentological and palynological data from a $350 \mathrm{~m}$ thick coalbearing succession intersected by borehole 945L_0022, drilled in the eastern Tete Province of Mozambique, which documents southwestern Gondwana’s Permian postglacial climate amelioration. Palynofacies data further support the environmental reconstructions interpreted from the sedimentary succession. Changes in the palynomorph assemblage document a shift from cold, to cool-temperate, to warmtemperate climatic conditions. This climate signature corresponds with observations from other depositional environments elsewhere in southern Africa, and thus enables correlation on a regional to interregional scale. Thick lacustrine deposits are described within the lower coal-bearing succession, reflecting the final glacial retreat, with melt waters supplying fresh water to the incipient lacustrine system. Lakes as characteristic postglacial sedimentary sinks are excellent palaeoclimate archives and the high Total Organic Carbon content of these fine-grained clastic sediments also makes them potential source rock targets for oil and gas.
\end{abstract}


Keywords: Palaeoclimate; Sedimentology; Palynology; Permian; Moatize sub-basin; Mozambique

\section{Introduction}

The Karoo-aged basins of southern Africa exhibit a nearly continuous sedimentary record from the Late Carboniferous (Pennsylvanian) to the Early Jurassic, and record a prominent period of Phanerozoic climate amelioration following the Gondwanan Carboniferous glaciation (Falcon, 1986, 1989; Cairncross, 1989, 2001; Wopfner, 2002; Catuneanu et al., 2005; Scheffler et al., 2006; Isbell et al., 2008; Scotese, 2016). Permian postglacial coals in particular are unique climate archives, and the palynological record of coal deposits of the Main Karoo Basin in South Africa has been recently studied with respect to climate signatures (Götz and Ruckwied, 2014; Ruckwied et al., 2014; Wheeler and Götz, 2016, 2017).

Recent exploration of coal in the eastern part of the Tete Province of Mozambique has made much new core material available. Palynological studies have so far focused on the stratigraphic placement of formations of the lower Karoo sequence (Lopes et al., 2014; Pereira et al., 2014), the Permian-Triassic transition (Pereira et al., 2016), and the climate history of the late Guadalupian-early Lopingian interval (Götz et al., 2017). Here, we report sedimentological and palynological data from Permian coal deposits intersected by a continuously cored borehole from the Moatize sub-basin. A preliminary palynostratigraphic framework of the Tete coals in relation to coals and black shales of the Main Karoo Basin in South Africa is also provided.

\section{Geological setting}

The coal-bearing Karoo basins of Mozambique form part of a network of riftrelated basins of south-central Africa (Johnson et al., 1996; Cairncross, 2001; Catuneanu et al., 2005) collectively ascribed to the Mid-Zambezi Basin (Cabora Bassa Basin of Catuneanu et al., 2005), the axis of which follows the fabric of the underlying Sanângoè Shear Zone in the Precambrian basement. The Zambezi Basin may be further divided into several sub-basins that are now disconnected due to Jurassic and Cretaceous extensional tectonics and subsequent erosion. From west to east these are termed the Chicôa-Mecúcoè (including the Mucanha-Vúzi sector), 
Sanângoè-Mefídézi, Moatize (or Moatize-Benga), Muarádzi and Minjova sub-basins, with northwest and southeast extensions to the N'Condédzi and Mutarara sub-basins (Vasconcelos, 2012; Fig. 1).

The borehole utilised in this study was collared in the Moatize sub-basin, which is located in the northwest of Mozambique along the Zambezi River Valley (Fig. 1). Here four main stratigraphic units are present within the Karoo Supergroup, designated, in ascending order, the Vúzi, Moatize, Matinde and Cádzi formations (Paulino et al., 2010; Fig. 2). The Vúzi, Moatize and Matinde formations host coal seams. Traditionally, six main coal zones have been distinguished in the Moatize Formation, which are variously given names, letters or numbers as codes (Neto, 1976; Cairncross, 2001). These have been referred to in ascending order as the Sousa Pinto, Chipanga, Bananeiras, Intermédia, Grande Falésia and André coal seams (Fig. 2), although their exact positions relative to various sequence boundaries are not yet well established. Due to the historic dominance of the Moatize area for coal mining, this seam stratigraphy has become the standard to which coal successions in other subbasins are compared and correlated.

Borehole 945L_0022 was drilled on International Coal Ventures Limited's (ICVL) 945L licence area, which covers an area of $98.8 \mathrm{~km}^{2}$ in the southwestern portion of the Moatize District, some $15 \mathrm{~km}$ southeast of the city of Tete. The borehole was collared in sandstones of the lower Matinde Formation and intersected the entire Lower Karoo Supergroup succession down to the basement contact at $343.79 \mathrm{~m}$ below surface. The six coal zones encountered are referred to by ICVL, from the base upwards as the A, B, C, F, J and K seams. Based on our current understanding of the sub-basin from the study of over 500 boreholes these equate to the Sousa Pinto (B), Chipanga (C), Bananeiras (F), Grande Falésia (J) and André (K) seams of the classic Moatize stratigraphy (Fig. 3). It should be noted that the lowermost (unnamed) seam belongs to the Vúzi Formation, and the A Seam to a unit that at present has not been assigned a formal stratigraphic nomenclature in Mozambique, but that was termed the “Transitional Member” by Lakshminarayana (2015). The Intermédia Seam was either not developed or was removed by erosion. An increase in coal rank with depth is recognized by vitrinite reflectance values ranging from $1.28 \%$ for the Grande Falésia (J) Seam to 1.51\% for the Sousa Pinto (B) Seam. 


\section{Materials and methods}

As part of a re-logging exercise for Rio Tinto Coal Mozambique Limitada (now ICVL) a detailed sedimentological documentation of borehole 945L_0022 is provided (Fig. 3). No coal was available as this material had already been sampled and analysed. Siltstones related to coal seams are however suitable for palynological analyses since they contain an auto- and allochthonous fraction of organic particles, thus documenting both the local depositional environment as well as climate-related changes within a stratigraphic succession. Carbonaceous siltstones in the floor and/or roof lithologies of the main coal seams were therefore targeted for this study and the palynological samples were also selected so as to cover different stages in the development of the sedimentary succession (Fig. 4). Sample 1 (343.30-343.45 m; Fig. 5a) was taken from the base of a coaly, carbonaceous succession that marks the top of the thinly (1.18 m) developed Vúzi Formation. Whilst this coal remains unnamed it is present in a number of other parts of the Moatize sub-basin and marks the boundary between the Vúzi Formation and the overlying coarse-grained sandstones of the “Transitional Member” (Lakshminarayana, 2015). It should be noted that this overlying succession (interval 342.90-312.00 m which hosts the A Seam) is not formally designated in the Moatize sub-basin, and is often erroneously included within the Vúzi or Moatize formations. Sample 2 (329.25-329.40 m; Fig. 5b) was taken from the roof of the A Seam, which is a sandstone hosted coal within the “Transitional Member”. Sample 3 (313.48-313.56 m) was taken from the floor of the B Lower Seam above the topmost medium- to coarse-grained sandstone of the “Transitional Member” and would be stratigraphically near the base of the Moatize Formation (if the Transitional Member is eventually given Formational status). Sample 4 (291.28-291.37 m; Fig. 5c) was taken from a carbonaceous siltstone succession above the carbonaceous diamictites (CS in Fig. 5c) that mark the termination of the B Upper Seam. Sample 5 (263.20-263.28 m; Fig. 5d) was taken from near the middle of a thick carbonaceous mudstone/siltstone unit in the lower Moatize Formation. Sample 6 (222.06-222.14 m; Fig. 6a) was taken from near the top of this carbonaceous mudstone/siltstone unit. Sample 7 (198.73-198.89 m; Fig. 6b) is a carbonaceous siltstone in the immediate roof to the C Seam, which marks the drowning phase of the seam development, near the top of the carbonaceous dominated lower Moatize Formation. Sample 8 (144.25-144.35 m; Fig. 6c) is from a 
carbonaceous siltstone that forms the immediate floor to the F Seam. The final sample (sample 9; 71.18-71.28 m) was taken from the floor of the J Seam (Fig. 6d).

Palynological samples were prepared using standard palynological processing techniques (Wood et al., 1996), including $\mathrm{HCl}$ (33\%) and $\mathrm{HF}$ (73\%) treatment for dissolution of carbonates and silicates, and saturated $\mathrm{ZnCl}_{2}$ solution $(\mathrm{D} \approx 2.2 \mathrm{~g} / \mathrm{ml}$ ) for density separation. Residues were sieved at $15 \mu \mathrm{m}$ mesh size and mounted in Eukitt, a commercial, resin-based mounting medium. For palynofacies analysis organic matter was grouped into phytoclasts, sporomorphs (pollen grains and spores), fresh water algae and degraded (DOM) and amorphous organic matter (AOM), following the classification scheme used in Götz and Ruckwied (2014). The relative percentages of these components are based on counting at least 300 particles per slide.

The Total Organic Carbon (TOC) content of sample 5, a black carbonaceous mudstone, was analysed using a Leco SC-632 elemental analyser, the amount of carbon being measured as carbon dioxide by IR detector.

\section{Sedimentology}

Borehole 945L_0022 intersected a clastic succession, comprised mainly of sandstones, siltstones, mudstones and coals, with the end of hole in anorthositic basement rocks of the Mesoproterozoic Tete Suite (Lächelt, 2004; GTK Consortium, 2006). This succession may be subdivided into a number of sequences bound by regional unconformities or their correlative conformities (Fig. 3). The basal part is formed by a thin interval of grey-green siltstones, capped by a $0.80 \mathrm{~m}$ thick coal seam (Sequence 1; Figs. 3, 5a). This thin succession represents the Vúzi Formation, which elsewhere in the basin may be up to $300 \mathrm{~m}$ thick, being composed of three different cycles, from boulder bed diamictites at the base, to very fine-grained mudstone and coal at the top. The thickness of the Vúzi Formation varies dramatically within the Moatize sub-basin as it infills an irregular basement topography (Lloyd and Hancox, 2016).

The lowermost Vúzi Formation coal is sharply overlain by a 50 m thick succession (Sequence 2) dominated by medium- to very coarse-grained (and pebbly) cross-stratified sandstones, with lesser siltstones and thin coals, which in turn is capped by the B Seam coals (Fig. 3). In borehole 945L_0022 this unit has an overall coarsening-upward motif, but elsewhere in the basin it may also first coarsen, then fine upwards. Each individual cycle within the unit tends to first coarsen, then fine 
upwards, being capped by either carbonaceous siltstone or coal development (A Seam; Fig. 5b). The B Seam is developed on the top of this overall coarsening-upward succession and marks the top of Sequence 2 (Fig. 3). The B Seam is a composite seam, being composed of two different coal plies (a 12.34 m thick B Lower and a $4.76 \mathrm{~m}$ thick B Upper) interbedded with fine-grained, matrix supported diamictites (labelled as CS in Fig. 5c).

In borehole 945L_0022 the top of Seam B is marked by a shift to a $74 \mathrm{~m}$ thick clastic succession (Sequence 3) dominated by horizontally laminated carbonaceous siltstones and mudstones (Figs. 5d, 6a), with fine- to coarse-grained diamictites present at certain intervals towards the base. In places the mudstone and siltstone units preserve comminuted fossil plant material. This unit becomes more sandstone rich up the stratigraphy, with a cross-stratified sandstone unit marking the end of the finegrained carbonaceous unit (Fig. 6a). The top of this sandstone unit is again fine grained and shows evidence of plant rootlet bioturbation. This unit also forms the immediate floor to the $13.85 \mathrm{~m}$ thick C Seam (Fig. 6b).

The C Seam is overlain by around $4.5 \mathrm{~m}$ of carbonaceous siltstones (Fig. 6b), whereas elsewhere in the basin the roof of the C Seam may be formed by the overlying coarse-grained, cross-stratified sandstone, which is regional in its extent and forms the base of Sequence 4 (Fig. 3).

Sequence 4 forms a composite section almost $90 \mathrm{~m}$ thick. The basal part of the succession is formed by four stacked, fining-upwards, medium- to very coarsegrained sandstone dominated units, which form an overall coarsening-upward motif (Fig. 3). The sandstones are internally structured by low angle cross-stratification. In places in the Moatize sub-basin various coals may be hosted in these sandstone units at the tops of the cycles. ICVL refer to these coals as D seams, but none are present in borehole 945L_0022. The upper part of the sequence is dominated by fine-grained carbonaceous dominated lithologies, including coal (F Seam; Fig. 6c). In borehole 945L_0022, the succession overlying the $14.76 \mathrm{~m}$ thick F Seam is dominated by very fine-grained, ripple cross-stratified carbonaceous sandstones, and a very distinctive unit around $6 \mathrm{~m}$ thick of interbedded ripple to horizontally cross-stratified sandstones and siltstones, that forms the uppermost part of the sequence (Fig. 3). In other parts of the basin, the succession above the F Seam may contain two additional coals, which ICVL refer to as the $\mathrm{G}$ and $\mathrm{H}$ seams, and that probably correlate with the Intermédia Seam elsewhere in the sub-basin. 
Sequence 5 begins with a coarse to very coarse-grained sandstone unit (Fig. 3), the base of which may be erosive into the underlying carbonaceous mudstones, and which also forms a regionally traceable boundary. The basal sandstone succession is formed by four stacked, fining-upwards units, which show an overall fining-upwards trend, with the final cycle being capped by a thin (3.42 m) coal seam (J Seam; Fig. 6d). The succession above the J Seam is formed by a $25 \mathrm{~m}$ thick sandstone-dominated unit comprised of two stacked fining-upwards cycles, the top of the uppermost of which forms the base to the uppermost K Seam (Fig. 3). The $10.34 \mathrm{~m}$ thick K Seam in turn is erosively overlain by the base of the sandstone units of the uppermost Sequence 6 which is not fully preserved in the studied borehole, and being formed by three individual medium- to coarse-grained fining upwards, cross-stratified sandstone dominated cycles.

\section{Palynostratigraphy}

In borehole 945L_0022 three palynomorph assemblages are distinguished (Fig. 4). From the base up samples 1 (from a siltstone near the top of the Vúzi Formation) through to sample 5 (from the B-C Seam interburden) represent assemblage I. Samples 6 and 7 (near the top of the thick carbonaceous mudstone/siltstone unit and the roof of the C Seam) and sample 8 (from the floor of the F Seam) represent assemblage II, and sample 9 (from the floor of the J Seam) represents assemblage III.

Assemblage I is dominated by monosaccate pollen grains (Cannanoropollis spp., Plicatipollenites sp., and Potonieisporites spp.), Florinites (first occurring in sample 5, in the B-C Seam interburden) and trilete spores (Punctatisporites spp., Verrucosisporites spp., Microbaculispora spp., and Calamospora spp.). Monocolpate pollen grains are represented by Cycadopites sp.. Bisaccate pollen grains occur in very low abundance, with non-taeniate elements (Alisporites sp. and Limitisporites sp.), and taeniate elements being very rare, with Protohaploxypinus sp. being present.

Assemblage II comprises praecolpate, monosaccate and bisaccate (non-taeniate and taeniate) pollen grains (Marsupipollenites striatus, Florinites sp., Potonieisporites spp., Alisporites spp., Limitisporites sp., Striatopodocarpites cancellatus and Protohaploxypinus limpidus) with non-taeniate elements being dominant. Spores include Apiculatisporites sp., Lophotriletes sp., Lundbladispora braziliensis, Punctatisporites sp., and Verrucosisporites spp.. 
Assemblage III is dominated by costate and taeniate bisaccate pollen grains including Vittatina spp., Weylandites lucifer, Lueckisporites virkkiae, Guttulapollenites hannonicus, Striatopodocarpites cancellatus and Protohaploxypinus spp..

\section{Palynofacies analysis}

Palynofacies of sample 1 (top Vúzi Formation) is characterized by a high proportion of small, opaque phytoclasts and degraded organic matter. Translucent particles are present in low abundance. Trilete spores and monosaccate pollen grains are dominant within the palynomorph group, bisaccates being very rare $(<2 \%)$. In sample 2 (roof A Seam) a change in the composition of the phytoclast group is observed with opaque particles of various sizes and shapes, large cuticle fragments and wood remains. Amorphous organic matter is recorded. Trilete spores and monosaccate pollen grains are the dominant elements within the palynomorph group. Sample 3 (floor B Lower Seam) shows a high percentage of degraded organic matter and poor preservation of palynomorphs. Equidimensional opaque phytoclasts are dominant. In sample 4 (above B Upper Seam) large phytoclasts, cuticles and amorphous organic matter are encountered as the dominant organic particles. Bisaccate pollen grains occur in very low abundance. Sample 5 (lower Moatize Formation carbonaceous siltstone) shows a striking increase in translucent phytoclasts of various sizes and shapes, a high proportion of trilete spores and an increase of bisaccate pollen grains (Fig. 7a). Freshwater algae (Tetraporina sp., Botryococcus sp.) and amorphous organic matter are also recorded. The present-day TOC of this organic-rich siltstone is 6.5\%. Sample 6 (top lower Moatize Formation carbonaceous siltstone) is characterized by a high percentage of large, opaque phytoclasts. A striking increase of bisaccate pollen grains is documented, non-taeniate elements being dominant. In sample 7 (roof C Seam) small, equidimensional phytoclasts are dominant, and palynomorphs highly fragmented (Fig. 7b). Sample 8 (floor F Seam) documents a striking increase in taeniate elements within the bisaccate group, and contains biostructured phytoclasts including gymnosperm tracheid fragments. In sample 9 (floor J Seam) taeniate bisaccate pollen grains are the dominant elements in the palynomorph group, and spores are present in low abundance. The phytoclast group is characterized by mainly opaque, equidimensional particles. 


\section{Palaeoenvironment and palaeoclimate reconstruction}

This section integrates the sedimentological and palynological data in order to interpret the prevailing depositional and climatic conditions (Fig. 4). The presence of faceted pebbles, large-scale soft sediment deformation and varved mudrocks in the Vúzi Formation (Rubino et al., 2015) shows it to be of glacial origin. In borehole 945L_0022 only the upmost part of the Vúzi Formation is present, and this is interpreted to represent deposition in glacial lakes and mires. The dominance of monosaccate pollen grains in sample 1 indicates cold climate.

The overlying “Transitional Member” is dominated by very poorly sorted, coarse-grained, cross-stratified sandstones, which overall form a coarsening-upward motif. These deposits are interpreted as a fluvially dominated prograding fan-delta, with the coal seams (A Seam) developed in the abandoned channel tracts. The more regionally correlatable B seams are interpreted as lake-margin mires. The change in the composition of phytoclasts from sample 2 with various sizes and shapes of opaque particles to a high percentage of degraded organic matter and poor palynomorph preservation in sample 3 to large phytoclasts, cuticles and amorphous organic matter preserved in sample 4 records this development from fan delta, abandoned river channel to lake-margin mires. Sample 3 shows a high proportion of degraded organic matter, plant debris and poor preservation of palynomorphs, indicating a high-energy hydrodynamic system prior to the abandonment phase that allowed for the development of the B Lower Seam. Sample 4 (immediate roof to the B Upper Seam) is interpreted to represent a swamp setting with large phytoclasts, cuticles and amorphous organic matter as the dominant organic particles. Samples 2 to 4 are still dominated by monosaccate pollen grains, indicative of prevailing cold climate conditions.

Based on the laminated nature of the carbonaceous siltstones and mudstones, the presence of fragmented macro plant fossils, freshwater algae (Tetraporina sp., Botryococcus sp.), amorphous organic matter and high percentages of translucent phytoclasts of various sizes and shapes, the basal part of Sequence 3 is interpreted to represent a lacustrine fill. The presence of amorphous organic matter in sample 5 is indicative of a stratified water column with anoxic bottom waters and an oxic upper layer (Tyson, 1995). A high TOC content is related to anoxic bottom water conditions with high potential of sedimentary organic matter preservation. In sample 5 bisaccate 
pollen grains are for the first time present with non-taeniate and taeniate elements, clearly marking a change in the upland flora related to climate amelioration.

Swamp conditions are reflected in sample 6 (top of the lacustrine succession), with large (200-500 $\mu \mathrm{m}$ ) phytoclasts pointing to in situ deposition with low energy transport. Sample 7 (siltstones in the immediate roof to the C Seam) is dominated by small, equidimensional phytoclasts and highly fragmented palynomorphs, showing fluvial reworking and abrasion. The stacked, fining-upwards cycles of Sequence 4 show it to be fluvially dominated, with the bedload dominance, grainsize and internal cross-stratification suggesting it to be a bedload dominated system, most likely of a braided river system. The overall coarsening-upward profile shows that this system was progradational, and its spatial setting above a lacustrine system suggests that this would represent deposition in a braid-delta system, with the uppermost carbonaceous (and coal) dominated part of the succession representing the channel abandonment phase. The low energy channel abandonment phase is also indicated by the wellpreserved biostructured phytoclasts in sample 8. A prominent increase from sample 6 to 8 in bisaccate pollen grains within both groups taeniate and non-taenite, nontaeniate elements still being most abundant, provides evidence of a cool-temperate climate.

Sequence 5 is also dominated by fining-upward, fluvially dominated crossstratified sandstones, with the channel abandonment phase being represented by carbonaceous siltstones and coal development. From the studied core it is however not possible to further differentiate the type of channel system. Palynofacies analysis of sample 9 (floor to the J Seam) shows it to contain a high percentage of opaque, equidimensional particles and spores being present, representing the waning phase of the fluvial system prior to swamp (coal seam) formation. In this stage spore diversity of the lowland flora is still low and windblown pollen grains from upland regions are still prevailing. The dominance of bisaccate taeniate pollen grains within the palynomorph group records the switch to warm-temperate climate conditions. Like Sequence 5, Sequence 6 is formed by three, fining-upward, bedload dominated cycles, which may be attributed to a fluvial system.

\section{Age and correlation}

A palynostratigraphic zonation of coal-bearing Permian successions of South Africa was established in the Witbank Coalfield by Falcon et al. (1984a) and applied 
to the Mucanha-Vúzi sector of the western Tete Province of Mozambique for coal seam identification and correlation (Falcon et al., 1984b). Biozones III (sub-zone F) and IV (sub-zones $\mathrm{G}$ and $\mathrm{H}$ ), representing a latest Cisuralian to Lopingian age, were identified within the two boreholes A3 and C3 studied from the western Tete Province by Falcon et al. (1984b) and comprise the Sulcatisporites-Protohaploxypinus SubAssemblage, Protohaploxypinus-Vittatina-Striatopodocarpites Sub-Assemblage, and Protohaploxypinus-Vittatina-Guttulapollenites-Lueckisporites Sub-Assemblage.

In assemblage I of the here studied borehole 945L_0022 from the eastern Tete Province, the palynomorph association of samples 1, 2, 3, and 4 may be correlated with Biozone I-B (Virkkipollenites-Plicatipollenites-Potonieisporites-Elilasaccites Sub-Assemblage) of Falcon et al. (1984a), whereas sample 5 yields a palynomorph spectrum similar to Biozone I-C with Florinites spp. being present (VirkkipollenitesPlicatipollenites-Potonieisporites-Florinites Sub-Assemblage). The succession between 343.30 and $291.37 \mathrm{~m}$ is thus interpreted as the stratigraphic equivalent of an interval including the No. 1 Coal Seam of the Witbank Coalfield (north-eastern Main Karoo Basin), whereas sample 5 at 263.20-263.28 m correlates with the lower No. 2 Coal Seam (Fig. 8). The entire interval between 343.30 and 263.28 m correlates with the lower part of the Prince Albert Formation of the northern and southern Karoo Basin, showing a similar palynomorph spectrum (Ruckwied et al., 2014; Wheeler and Götz, 2017). In assemblage II, the palynomorph association of samples 6 and 7 is correlated with Biozone II-D (Sulcatisporites-Virkkipollenites-PlicatipollenitesPotonieisporites Sub-Assemblage) of Falcon et al. (1984a), whereas sample 8 shows a palynomorph spectrum characteristic of Biozone III-F (SulcatisporitesProtohaploxypinus (Transition) Sub-Assemblage). The succession between 222.06 and $144.35 \mathrm{~m}$ is thus interpreted to represent the stratigraphic equivalent of an interval including the upper No. 2 Coal Seam of the Witbank Coalfield and the middle Prince Albert Formation of the northern and southern Karoo Basin; sample 8 at 144.25144.35 m correlates with the No. 4 Coal Seam of the Witbank Coalfield and the upper Prince Albert Formation (Ruckwied et al., 2014). The palynomorph association of sample 9, representing assemblage III, resembles elements characteristic of Biozone IV-G (Protohaploxypinus-Vittatina-Striatopodocarpites Sub-Assemblage) of Falcon et al. (1984a), and sample horizon $71.18-71.28 \mathrm{~m}$ is correlated with the No. 5 Coal Seam of the Witbank Coalfield, and with the lower Whitehill Formation of the northern and southern Karoo Basin (Ruckwied et al., 2014). We therefore place the 
entire succession chronostratigraphically into the upper Cisuralian to lowermost Guadalupian, with an Artinskian age of assemblage I, a Kungurian age of assemblage II, and a Roadian age of assemblage III (Fig. 4).

In borehole 948L_0005, drilled in 948L licence area southeast of 945L licence area, palynomorph assemblages revealed a younger (late Guadalupian-Lopingian) age (Götz et al., 2017), resembling assemblages of biozones IV-H and IV- $\mathrm{H}^{1}$ (Falcon et al., 1984a) with the dominant elements Guttulapollenites hannonicus and Lueckisporites virkkiae, first occurring in Biozone IV-G. Palynomorph assemblages from both boreholes document continuous sedimentation from the Cisuralian (Artinskian) to early Lopingian (Wuchiapingian) in the eastern Tete Province (Fig. 8). Palynomorph assemblages described by Lopes et al. (2014) and Pereira et al. (2014) from boreholes studied in the Moatize sub-basin, east of the 945L licence area, were interpreted to indicate a Kungurian-Roadian age, the association being similar to biozones III-F and IV-G of Falcon (1975, 1978) and Falcon et al. (1984a) and comparable with data from Zambia (Utting, 1978; Nyambe and Utting, 1997), Tanzania (Semkiwa et al., 1998, 2003; Kalkreuth et al., 1999) and Botswana (Modie, 2007). In a following study, Pereira et al. (2016) identified late Permian (late Changhsingian)-Early Triassic (Induan) palynomorph assemblages in boreholes drilled some kilometers west of those revealing Kungurian-Roadian assemblages (Lopes et al., 2014; Pereira et al., 2014).

Previously, the coals of the Moatize Formation of the Tete Province were interpreted as deposits of Artinskian-Kungurian age (Cairncross, 2001). From the new palynological data recently obtained from exploration boreholes (Lopes et al., 2014; Pereira et al., 2014, 2016; Götz et al., 2017; this study) a much wider and more precise stratigraphical range of coals within the Karoo sequence of the Moatize subbasin can be inferred. The first coals occur in the early Artinskian, in the uppermost part of the Vúzi Formation, and the uppermost coal deposits within the Matinde Formation reveal a late Lopingian age (Pereira et al., 2016; Götz et al., 2017). Thus, coal accumulation seems to have occurred continuously over a much longer time interval than previously assumed spanning the Early to Late Permian.

\section{Discussion}

Integrated sedimentological and palynofacies analyses reveal different depositional environments related to swamp, lake and fluvial regimes. The lower part 
of the succession is here interpreted to reflect postglacial deposition on a coarsegrained fluvio-deltaic plain (Fig. 4), with the development of broad swamp areas in the abandoned channel tracts and on the lacustrine fringe (lake margin coals - B Seam).

From the top of the B Upper Seam the succession marks a rising in the regional water table, and the development of large stratified lake basins, as known elsewhere in South-Central Africa (Kreuser and Woldu, 2010). The formation of these stratified lake basins during the deglaciation phase of central southwestern Gondwana seems to reflect the final glacial retreat. Organic-rich lacustrine shales overlying the Sousa Pinto Seam were previously reported by Pendkar et al. (2014) from outcrop sections along the Moatize River, north of 945 licence area. The documentation of such organic-rich lake deposits in boreholes intersecting the coal-bearing Moatize Formation of Mozambique is crucial to assess their spatio-temporal extent. The present study reiterates the importance of outcrop analogue studies for the offshore seismic interpretations as outlined by Pendkar et al. (2014). Furthermore, the TOC content of these organic-rich siltstones of $6.5 \%$ classifies these lake deposits as potential source rock for oil and gas. The age based on palynology indicates a slightly younger age (Artinskian) (Figs. 4, 8) than the late Asselian to early Sakmarian age previously reported from other parts of southern and eastern Africa (Kreuser and Woldu, 2010). The Artinskian age of lake deposits detected in the eastern Tete Province does however correspond to the age of the lacustrine interval recorded in the No. 2 Coal Seam of the South African Witbank and Highveld coalfields (Götz and Ruckwied, 2014; Wheeler and Götz, 2016, 2017). A time interval of about 4-5 Ma for the lacustrine phase, as proposed by Kreuser and Woldu (2010) from data of the southwestern Tanzanian Ruhuhu Basin, is here corroborated. Radiometric dates are however not yet available to confirm this age range and to provide precise dating, respectively.

The base of Sequence 4 documents a changeover from lake-margin, to fluvially deposited sandstone hosted coals. The bedload dominance, coarse grainsize and internal stratification all point to high energy condition of flow, probably within a braid-delta environment. Elsewhere in the basin, outcrop sections along the Morrongoze River allow for the lower part of this succession to be definitely documented as being of a braided nature, changing over to a coarse-grained meander belt prior to the deposition of the Bananeiras (F) Seam. 
Palynomorph assemblages identified in borehole 945L_0022 show striking changes within the succession. The lower part (samples 1 to 5), including seam A and $\mathrm{B}$, is dominated by monosaccate pollen grains and trilete spores. The middle part of the section (samples 6 to 8), including seams $\mathrm{C}$ and $\mathrm{F}$, documents a prominent increase in bisaccate pollen grains within both groups taeniate and non-taenite, though non-taeniate elements are most abundant. In the upper part (sample 9), bisaccate taeniate pollen grains are the dominant constituents within the palynomorph group. For climate reconstruction using palynomorph assemblages one has to carefully consider the different effects of local depositional to global climate signatures. Thus, the change in the pollen-producing upland vegetation, not reflecting local changes within lowland swamp and lake settings, is most likely the best candidate to record climatic shifts. From this background and based on recently described changes in the pollen record of the Permian coal-bearing successions of the Moatize sub-basin (Lopes et al., 2014; Pereira et al., 2014, 2016; Götz et al., 2017), the studied succession intersected by borehole 945L_0022 is interpreted to capture the change from cold to cool-temperate to warm-temperate climate conditions with the most prominent signal recorded in the lower Moatize Formation. In sample 5 bisaccate pollen grains are for the first time present with non-taeniate and taeniate elements, clearly marking a change in the upland flora. This signature, indicating the switch from cold to cool-temperate conditions, was previously detected in the upper No. 2 Coal Seam of the Witbank and Highveld coalfields in South Africa (Götz and Ruckwied, 2014; Wheeler and Götz, 2016, 2017) in various depositional settings, and thus allows for regional correlation (Fig. 8). The contemporaneous occurrence of lake deposits within the No. 2 Coal Seam of South Africa and a thick lacustrine interval in the coal-bearing Moatize Formation of Mozambique marks this prominent climate change. Consequently, glaciers still characterized the upland regions during the late Cisuralian and Gondwanan glaciation terminated much later as previously reported (Visser, 1987, 1993, 1997; Wopfner, 1999; Scheffler et al., 2003; Fielding et al., 2008). For the Moatize sub-basin a high-resolution palynological dataset is however still required to pinpoint climate signals supported by a robust palynostratigraphic framework. Ultimately, this information will enable us to refine Permian climate models for Gondwana, as well as intra-Gondwanan correlation, and will be addressed in ongoing research. 


\section{Conclusions}

Cisuralian-Guadalupian coal-bearing deposits of the Moatize sub-basin record a prominent change in basin fill related to climate amelioration. Palynological data revealing climate signatures are seen as a powerful stratigraphic tool for interregional correlations of Gondwanan coals, since intrabasinal facies shift and interbasinal facies differences make interregional correlation of distinct coal seams based on lithologies difficult. The coal-bearing succession intersected in borehole 945L_0022 captures a shift from cold to cool-temperate to warm-temperate climate conditions. The Artinskian-Roadian age determined for the succession is in accordance with recently published data from different boreholes of the Moatize sub-basin, and suggests a younger age of the Moatize coals than previously assumed. In comparison to the coalbearing interval of the Main Karoo Basin of South Africa, a wider stratigraphic range of coal deposits is thus most likely. Additionally, the development of a stratified lake basin is documented in the lower Moatize Formation, representing a characteristic feature of postglacial environments of southern Africa. The economic value of such lake deposits showing high TOC values has to be assessed by future research. Ongoing studies thus aim to establish an integrated stratigraphic framework of the Karoo sequence of the Moatize sub-basin, including climatic signatures to further develop intra-Gondwanan correlation schemes.

\section{Acknowledgements}

We kindly acknowledge Rio Tinto and International Coal Ventures Limited for permission to sample borehole 945L_0022. This study was partly funded by the National Research Foundation of South Africa (NRF), grant no. 94589, and performed according to the Russian Government Program for Competitive Growth of Kazan Federal University among World's Leading Scientific and Education Centers. The very constructive reviews and valuable comments by Joan Esterle (University of Queensland) and Paulo Fernandes (Universidade do Algarve) have greatly improved our manuscript.

\section{References}

Bangert, B., Stollhofen, H., Lorenz, V., Armstrong, R., 1999. The geochronology and significance of ash-fall tuffs in the glaciogenic Carboniferous-Permian Dwyka Group of Namibia and South Africa. Journal of African Earth Sciences 29, 33-49. 
Cairncross, B., 1989. Paleodepositional environments and tectonosedimentary controls of the postglacial Permian coals, Karoo Basin, South Africa. International Journal of Coal Geology 12, 365-380.

Cairncross, B., 2001. An overview of the Permian (Karoo) coal deposits of southern Africa. Journal of African Earth Sciences 33, 529-562.

Catuneanu, O., Wopfner, H., Eriksson, P.G., Cairncross, B., Rubidge, B.S., Smith, R.M.H., Hancox, P.J., 2005.The Karoo basins of south-central Africa. Journal of African Earth Sciences 43, 211-253.

Falcon, R.M.S., 1975. Palyno-Stratigraphy of the Lower Karroo sequence in the central Sebungwe District, Mid-Zambezi Basin, Rhodesia. Palaeontologica Africana 18, 1-29.

Falcon, R.M.S., 1978. A palynological comparison of Karoo sediments on opposite sides of the Rhodesian Watershed with stratigraphic application. PhD Thesis, University of the Witwatersrand, Johannesburg, 480 pp.

Falcon, R.M.S., 1986. A brief review of the origin, formation, and distribution of coal in southern Africa. In: Anhaeusser, C.R., Maske, S. (Eds.), Mineral Deposits of Southern Africa, Vol. II. Geological Society of South Africa, Johannesburg, pp. 1879-1898.

Falcon, R.M.S., 1989. Macro and micro-factors affecting coal-seam quality and distribution in southern Africa with particular reference to the No. 2 seam, Witbank Coalfield, South Africa. International Journal of Coal Geology 12, 681731.

Falcon, R.M.S., Pinheiro, H.J., Sheperd, P., 1984a. The palynobiostratigraphy of the major coal seams in the Witbank Basin with lithostratigraphic, chronostratigraphic and palaeoclimatic implications. Comunicações dos Serviços Geológicos Portugal 70, 215-243.

Falcon, R.M.S., Lemos de Sousa, M.J., Pinheiro, H.J., Marques, M.M., 1984b. Petrology and palynology of Mozambique coals - Mucanha-Vúzi Region. Comunicações dos Serviços Geológicos Portugal 70, 321-338.

Fielding, C.R., Frank, T.D., Isbell, J.L. (Eds.), 2008. Resolving the Late Paleozoic Ice Age in Time and Space. Geological Society of America Special Paper 441, 354 pp.

Götz, A.E., 2015. Palynological records of Gondwana’s mid-Permian climate amelioration: New insights from black shale deposits (Collingham Formation, South Africa). Geophysical Research Abstracts Vol. 17, abstract no. 2315. 
Götz, A.E., Ruckwied, K., 2014. Palynological records of the Early Permian postglacial climate amelioration (Karoo Basin, South Africa). Palaeobiodiversity and Palaeoenvironments 94 (2), 229-235.

Götz, A.E., Hancox, P.J., Lloyd, A., 2017. Permian climate change recorded in palynomorph assemblages of Mozambique (Moatize Basin, eastern Tete Province). Acta Palaeobotanica 57 (1), 3-11.

Götz, A.E., Ruckwied, K., Wheeler, A., 2018. Marine flooding surfaces recorded in Permian black shales and coal deposits of the Main Karoo Basin (South Africa): implications for basin dynamics and cross-basin correlation. International Journal of Coal Geology 190, 178-190.

GTK Consortium, 2006. Map Explanation. Geology of Degree Sheets MECUMBURA, CHIOCO, TETE, TAMBARA, GURO, CHEMBA, MANICA, CATANDICA, GORONGOSA, ROTANDA, CHIMOIO e BEIRA, Mozambique. Ministério dos Recursos Minerais, Direcção Nacional de Geologia, Maputo, Volume 2, sheets 1631-1934.

Isbell, J.L., Cole, D.I., Catuneanu, O., 2008. Carboniferous-Permian glaciation in the main Karoo Basin, South Africa: stratigraphy, depositional controls, and glacial dynamics. In: Fielding, C.R., Frank, T.D., Isbell, J.L. (Eds.), Resolving the Late Paleozoic Ice Age in Time and Space. GSA Special Paper 441, 71-82.

Johnson, M.R., van Vuuren, C.J., Hegenberger, W.F., Key, R., Shoko, U., 1996. Stratigraphy of the Karoo Supergroup in southern Africa: an overview. Journal of African Earth Sciences 23, 3-15.

Kalkreuth, W., Holz, M., Cazzulo-Klepzig, M., Marques-Toigo, M., Utting, J., Semkiwa, P., 1999. A comparative study of the geology, petrology and palynology of Permian coals in Tanzania and southern Brazil. Journal of African Earth Sciences 29, 91-104.

Kreuser, T., Woldu, G., 2010. Formation of euxinic lakes during the deglaciation phase in the Early Permian of East Africa. In: Lópes-Gamundí, O.R., Buatois, L.A. (Eds.), Late Palaeozoic Glaciation Events and Postglacial Transgressions in Gondwana. GSA Special Paper 468, 101-112.

Lächelt, S., 2004. The Geology and Mineral Resources of Mozambique. National Directorate of Geology, Maputo, Mozambique, 515 pp. 
Lakshminarayana, G., 2015. Geology of Barcode type coking coal seams, Mecondezi sub-basin, Moatize Coalfield, Mozambique. International Journal of Coal Geology 146, 1-13.

Lloyd, A., Hancox, P.J., 2016. The coal deposits of Mozambique. Abstracts of the GSSA African Exploration Showcase. Geological Society of South Africa, Johannesburg, South Africa, pp. 15-17.

Lopes, G., Pereira, Z., Fernandes, P., Marques, J., 2014. Datação palinológica dos sedimentos glaciogénicos da Formação Tilítica de Vúzi, sondagem ETA 65, Bacia Carbonífera de Moatize-Minjova, Moçambique: resultados preliminares. Comunicações Geológias 101, 481-484.

Lucas, S.G., Shen, S.Z., 2018. The Permian timescale: an introduction. In: Lucas, S.G., Shen, S.Z. (Eds.), The Permian Timescale. Geological Society, London, Special Publications 450, 1-19.

McKay, M.P., Weislogel, A.L., Fildani, A., Brunt, R.L., Hodgson, D.M., Flint, S.S., 2015. U-PB zircon tuff geochronology from the Karoo Basin, South Africa: implications of zircon recycling on stratigraphic age controls. International Geology Review 57, 393-410.

Modie, B.N., 2007. The Palaeozoic palynostratigraphy of the Karoo Supergroup and palynofacies insight into palaeoenvironmental interpretations, Kalahari Karoo Basin, Botswana. PhD Thesis, Université de Bretagne Occidentale, Brest, 316 pp. Neto, J.N., 1976. Coal deposits of Mozambique. In: Muir, W.L.G. (Ed.), Coal Exploration. Proceedings of the 1st International Coal Symposium, London, pp. 642-647.

Nyambe, I.A., Utting, J., 1997. Stratigraphy and palynostratigraphy, Karoo Supergroup (Permian and Triassic), mid-Zambesi Valley, southern Zambia. Journal of African Earth Sciences 24, 563-583.

Paulino, F., Vasconcelos, L., Marques, J., 2010. Karoo Stratigraphy in Mozambique. New Units. Abstracts of the X Congresso de Geoquímica dos Países de Língua Portuguesa. Universidade do Porto, Porto, Portugal, pp. 1-10.

Pendkar, N., Rubino, J.-L., Baby, J.-B.G., Lung, S.S.S., Prasetyotomo, W., 2014. Lower Karoo sedimentation in Moatize Basin, Mozambique: Analogue for understanding the deep rift sequence in offshore Rovuma Basin. Abstracts of the International Petroleum Technology Conference. IPTC, Kuala Lumpur, Malaysia, pp. 1-11. 
Pereira, Z., Lopes, G., Fernandes, P., Marques, J., 2014. Estudo palinostratigráfico da sondagem ETA 72 do Karoo Inferior da Bacia Carbonífera de Moatize-Minjova, Moçambique: resultados preliminares. Comunicações Geológias 101, 543-546.

Pereira, Z., Fernandes, P., Lopes, G., Marques, J., Vasconcelos, L., 2016. The Permian-Triassic transition in the Moatize-Minjova Basin, Karoo Supergroup, Mozambique: A palynological perspective. Review of Palaeobotany and Palynology 226, 1-19.

Rubino, J.L., Baby, G., Pendkar, N., Vasconcelos, L., Mussa, A., Lung, S.S.S., 2015. Glacial, peri-glacial and fluvio-lacustrine sequences in the Lower and Middle Karoo Supergroup in the Tete Basin (Mozambique). Abstracts of the $15^{\mathrm{e}}$ Congrès Biennal de Sédimentologie de l’Association des Sédimentologistes Français. ASF, Chambery, France, pp. 67-68.

Ruckwied, K., Götz, A.E., Jones, P., 2014. Palynological records of the Permian Ecca Group (South Africa): Utilizing climatic icehouse-greenhouse signals for cross basin correlations. Palaeogeography, Palaeoclimatology, Palaeoecology 413, 167172.

Scheffler, K., Hoernes, S., Schwark, L., 2003. Global changes during CarboniferousPermian glaciation of Gondwana: Linking polar and equatorial climate evolution by geochemical proxies. Geology 31, 605-608.

Scheffler, K., Buehmann, D., Schwark, L., 2006. Analysis of late Palaeozoic glacial to postglacial sedimentary successions in South Africa by geochemical proxies Response to climate evolution and sedimentary environment. Palaeogeography, Palaeoclimatology, Palaeoecology 240, 184-203.

Scotese, C., 2016. A new global temperature curve for the Phanerozoic. GSA Annual Meeting Denver, Colorado, Abstracts with Programs 48 (7), Paper No. 74-31, doi: 10.1130/abs/2016AM-287167.

Semkiwa, P., Kalkreuth, W., Utting, J., Mayagilo, F., Mpanju, F., Hagemann, H., 1998. The geology, petrology, palynology and geochemistry of Permian coal basins in Tanzania. 1. Namwele-Mkomolo, Muze and Galula coalfields. International Journal of Coal Geology 36, 63-110.

Semkiwa, P., Kalkreuth, W., Utting, J., Mpanju, F., Hagemann, H., 2003. The geology, petrology, palynology and geochemistry of Permian coal basins in Tanzania: 2. Songwe-Kiwira Coalfield. International Journal of Coal Geology 55, 157-186. 
Tyson, R.V., 1995. Sedimentary Organic Matter: Organic Facies and Palynofacies. Chapman \& Hall, London, 615 pp.

Utting, J., 1978. The Karroo Stratigraphy of the Northern Part of the Luangwa Valley. Geological Survey Zambia, Memoir 4, 64 pp.

Vasconcelos, L.S., 2009. Coal in Mozambique. Proceedings of the 3rd Symposium on Gondwana Coals. PUCRS, Porto Alegre, Brazil, pp. 1-49.

Vasconcelos, L.S., 2012. Overview of the Mozambique Coal Deposits. Proceedings of the 34th International Geological Congress 2012. Australian Geosciences Council, Brisbane, Australia, pp. 1-6.

Visser, J.N.J., 1987. The palaeogeography of part of southwestern Gondwana during the Permo-Carboniferous glaciation. Palaeogeography, Palaeoclimatology, Palaeoecology 61, 205-219.

Visser, J.N.J., 1993. A reconstruction of the late Palaeozoic ice sheet on southwestern Gondwana. Proceedings of the $8^{\text {th }}$ Gondwana Symposium 1991, Hobart, Tasmania, Australia. A.A. Balkema, Rotterdam, pp. 449-458.

Visser, J.N.J., 1997. Deglaciation sequences in the Permo-Carboniferous Karoo and Kalahari basins of southern Africa. A tool in the analysis of cyclic glaciomarine basin fills. Sedimentology 44, 507-521.

Wheeler, A., Götz, A.E., 2016. Palynofacies patterns of the Highveld coal deposits (Karoo Basin, South Africa): Clues to reconstruction of palaeoenvironment and palaeoclimate. Acta Palaeobotanica 56 (1), 3-15.

Wheeler, A., Götz, A.E., 2017. Palynofacies as a tool for high-resolution palaeoenvironmental and palaeoclimatic reconstruction of Gondwanan post-glacial coal deposits: No. 2 Coal Seam, Witbank Coalfield (South Africa).

Palaeobiodiversity and Palaeoenvironments 97 (2), 259-271.

Wood, G.D., Gabriel, A.M., Lawson, J.C., 1996. Palynological techniques processing and microscopy. In: Jansonius, J., McGregor, D.C. (Eds.), Palynology: Principles and Applications, Vol. 1. American Association of Stratigraphic Palynologists Foundation, Dallas, pp. 9-50.

Wopfner, H., 1999. The Early Permian deglaciation event between East Africa and northwestern Australia. Journal of African Earth Sciences 29, 77-90.

Wopfner, H., 2002. Tectonic and climatic events controlling deposition in Tanzanian Karoo basins. Journal of African Earth Sciences 34, 167-177. 


\section{Figure captions}

Fig. 1. Study area and sub-basins (Chicôa-Mecúcoè, Sanângoè-Mefídézi, Moatize (or Moatize-Benga), Muarádzi, Minjova, N'Condédzi and Mutarara) of the Mid-Zambezi Basin, Mozambique. Falcon et al. (1984b) investigated boreholes from the MucanhaVúzi region (highlighted in red) in the western Tete Province. Borehole 945L_0022 (this study; marked with red star) is located in the Moatize sub-basin (highlighted in red), eastern Tete Province.

Fig. 2. Coal zones of the Moatize Formation (Sousa Pinto, Chipanga, Bananeiras, Intermédia, Grande Falésia and André), Moatize sub-basin, eastern Tete Province, and their stratigraphic position (Cisuralian/Guadalupian) based on the relation to the underlying glaciofluvial deposits of the Vúzi Formation which is to date correlated with the Pennsylvanian-early Cisuralian Dwyka Group of the Main Karoo Basin, South Africa (Vasconcelos, 2009). However, the top of the Vúzi Formation and base of the Moatize Formation was recently dated as Kungurian/Roadian, i.e., late Cisuralian-early Guadalupian (Lopes et al., 2014), and Pereira et al. (2016) identified the Permian-Triassic boundary within the overlying Matinde Formation.

Fig. 3. Detailed sedimentological log of borehole 945L_0022 with intersected coal seams (A-K) and sequence interpretation. Abbreviations used: Fm. = Formation; Trans. Mb. = "Transitional Member” (sensu Lakshminarayana, 2015); Mesoproter. = Mesoproterozoic; t.d. = total depth; mbs = metre below surface; Lithology: $\mathrm{C}=$ coal, $\mathrm{m}=$ mudstone, $\mathrm{sl}=$ siltstone, $\mathrm{vf}=$ very fine-grained sandstone, $\mathrm{f}=$ fine-grained sandstone, $\mathrm{m}=$ medium-grained sandstone, $\mathrm{c}=$ coarse-grained sandstone, $\mathrm{vc}=$ very coarse-grained sandstone, $\mathrm{Di}=$ diamictite.

Fig. 4. Stratigraphic position of the coal-bearing succession intersected by borehole 945L_0022 with the main seams encountered (A-K), position of the palynological samples (1-9), depositional environments, and inferred climate shift based on palynomorph assemblages (I-III). Abbreviations used: V. = Vúzi Formation; Tr. Mb. = “Transitional Member” (sensu Lakshminarayana, 2015); Mat. = Matinde Formation. 
Fig. 5. Borehole 945L_0022, lower part of the intersected succession. (a) Sample 1 (343.30-343.45 m) taken from the base of the coaly unit marking the top of the Vúzi Formation. (b) Sample 2 (329.25-329.40 m) taken from the top of the lower (unsampled) coaly unit of the A Seam. (c) Sample 4 (291.28-291.37 m) taken from the carbonaceous siltstone in the roof of the B Seam. (d) Sample 5 (263.20-263.28 m) taken from the middle of the thick carbonaceous succession that marks the lacustrine fill. Abbreviations used: Tr. Mb. = Transitional Member, Fm. = Formation, $\mathrm{CS}=$ carbonaceous diamictites.

Fig. 6. Borehole 945L_0022, upper part of the intersected succession. (a) Sample 6 (222.06-222.14 m) taken from near the top of the thick lacustrine carbonaceous fines succession. (b) Sample 7 (198.73-198.89 m) taken from the carbonaceous siltstone in the roof of the C Seam. (c) Sample 8 (144.25-144.35 m) taken from the immediate floor to the F Seam. (d) Sample 9 (71.18-71.28 m) taken from the immediate floor of the J Seam.

Fig. 7. Palynofacies of lacustrine and fluvial deposits. (a) Lacustrine facies (sample 5) is characterized by a high variety of translucent and opaque phytoclast sizes and shapes, trilete spores and bisaccate pollen grains; bp - bisaccate (non-taeniate) pollen grains, opb - opaque blade-shaped phytoclasts, ope - opaque equidimensional phytoclasts, sp - trilete spores, tp - translucent phytoclasts. (b) Fluvial facies (sample 7) shows a high percentage of small, equidimensional opaque phytoclasts (ope) and degraded organic matter (DOM).

Fig. 8. Correlation scheme of Mozambican and South African coal deposits and black shales based on new palynological data from boreholes from the eastern Tete Province (Götz et al., 2017; this study), and the northern and southern Main Karoo Basin (Ruckwied et al., 2014; Götz, 2015; Götz et al., 2018). Radiometric dates from the Ecca Pass section (marked with stars: base Collingham Formation $268 \pm 3.2 \mathrm{Ma}$; Ripon Formation 262.5 \pm 3.0 Ma) from McKay et al. (2015); date of the base of the Prince Albert Formation (marked with diamond: $288 \pm 3.0 \mathrm{Ma}$ ) from Bangert et al. (1999). Permian timescale from Lucas and Shen (2018). L. = Lopingian, Fm. = Formation. Numbers 1 to 5 in the Witbank Coalfield column indicate the coal seams No. 1 to No. 5; numbers and letters in the Mozambique column indicate the coal 
seams encountered in the boreholes A3 and C3 (Mucanha-Vúzi sector, western Tete Province) and boreholes 945L_0022 and 948L_0005 (Moatize sub-basin, eastern Tete Province). Black bars in the No. 2 Coal Seam (Witbank Coalfield) and below the C Seam (eastern Tete Province) indicate the prominent lake interval. 


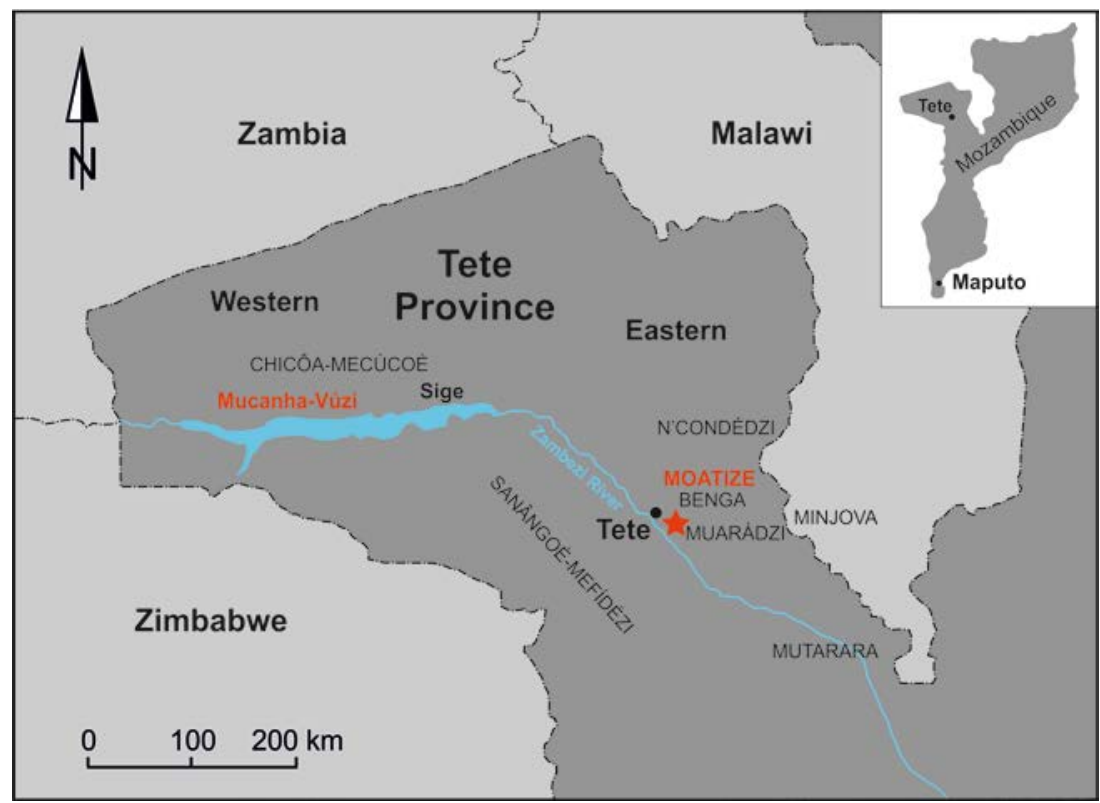

Figure 1

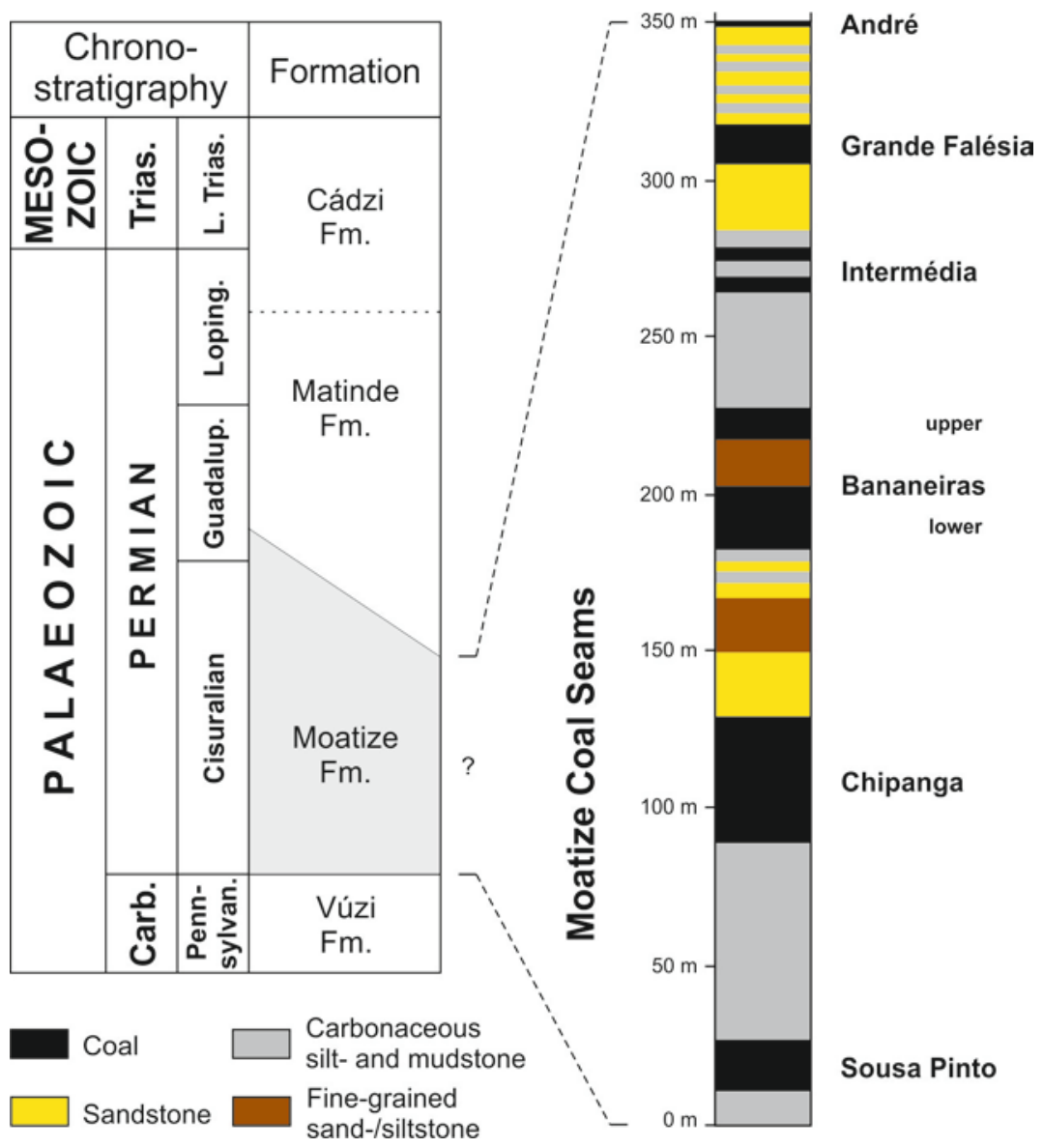

Figure 2 


\section{Stratigraphy Lithology Coal seam Sequence Density log (G/C3)}

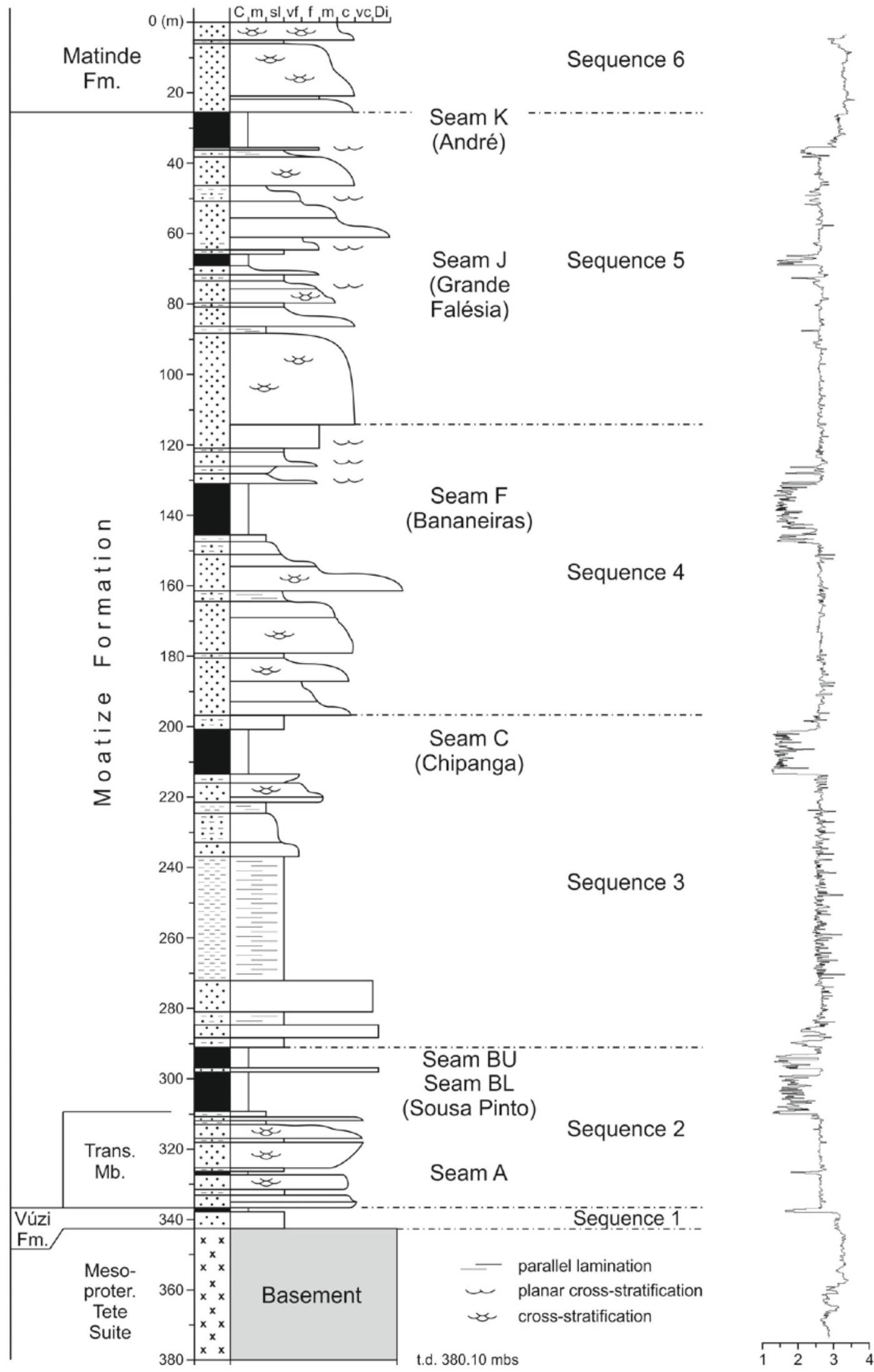

Figure 3 


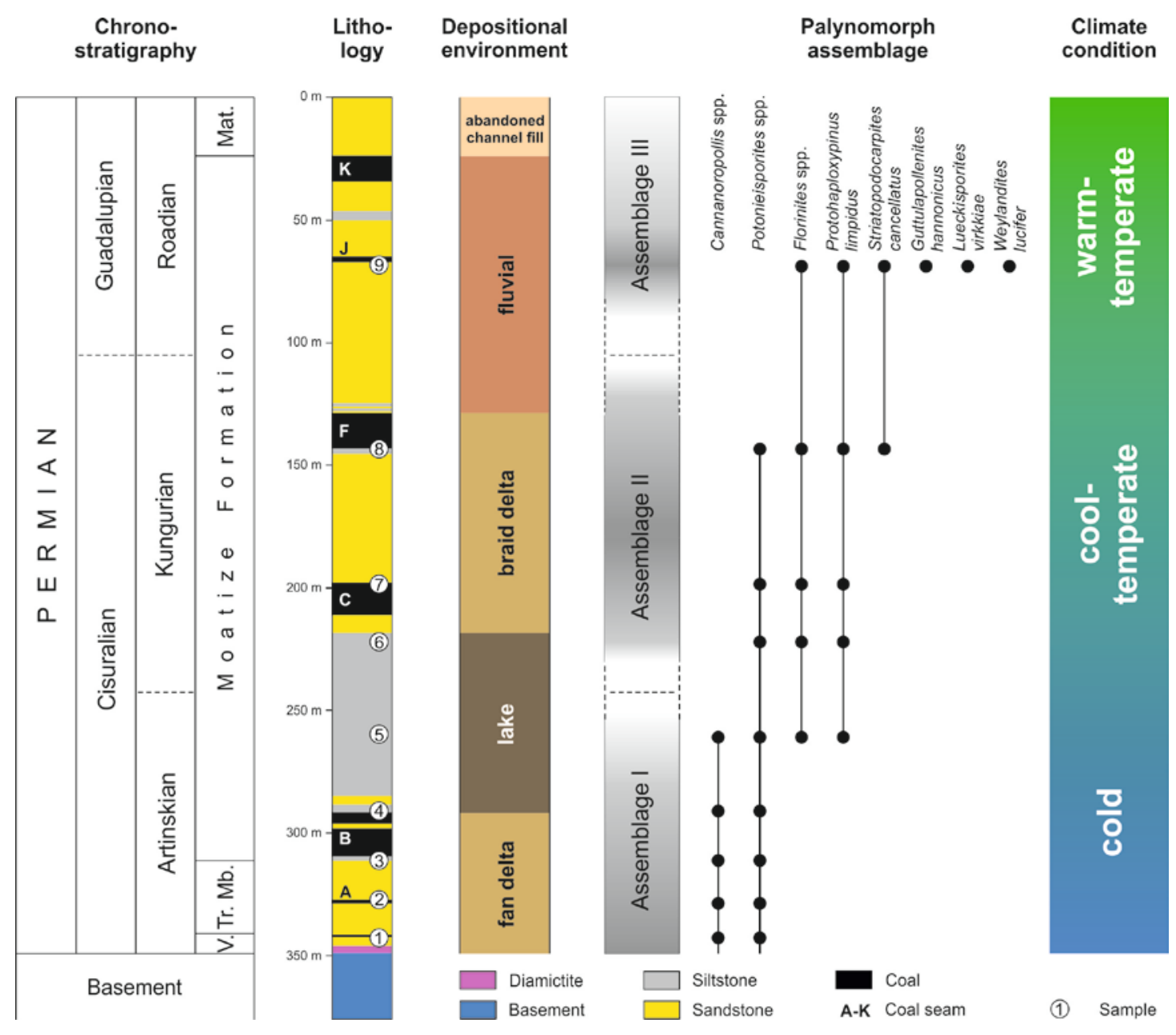

Figure 4 

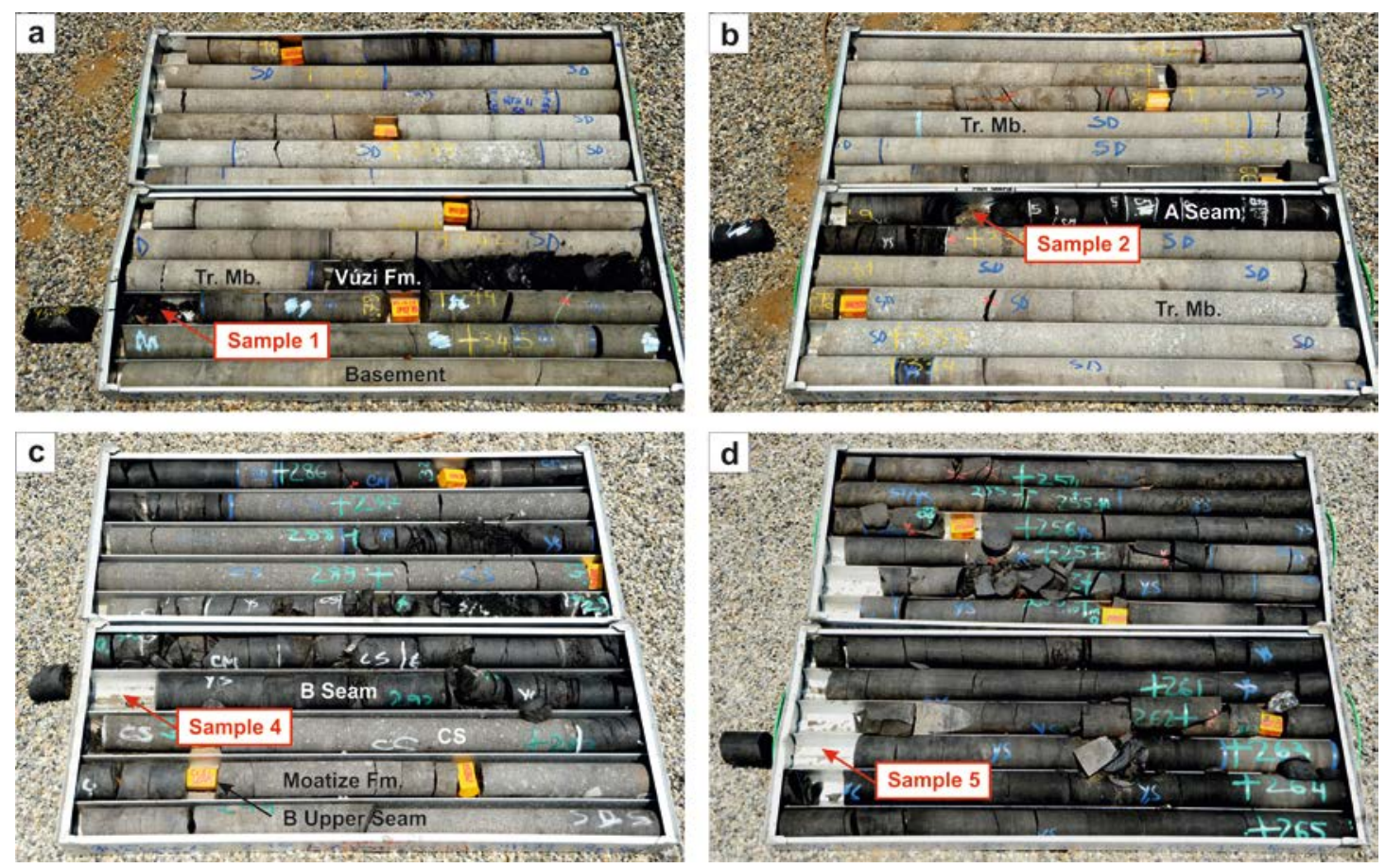

Figure 5
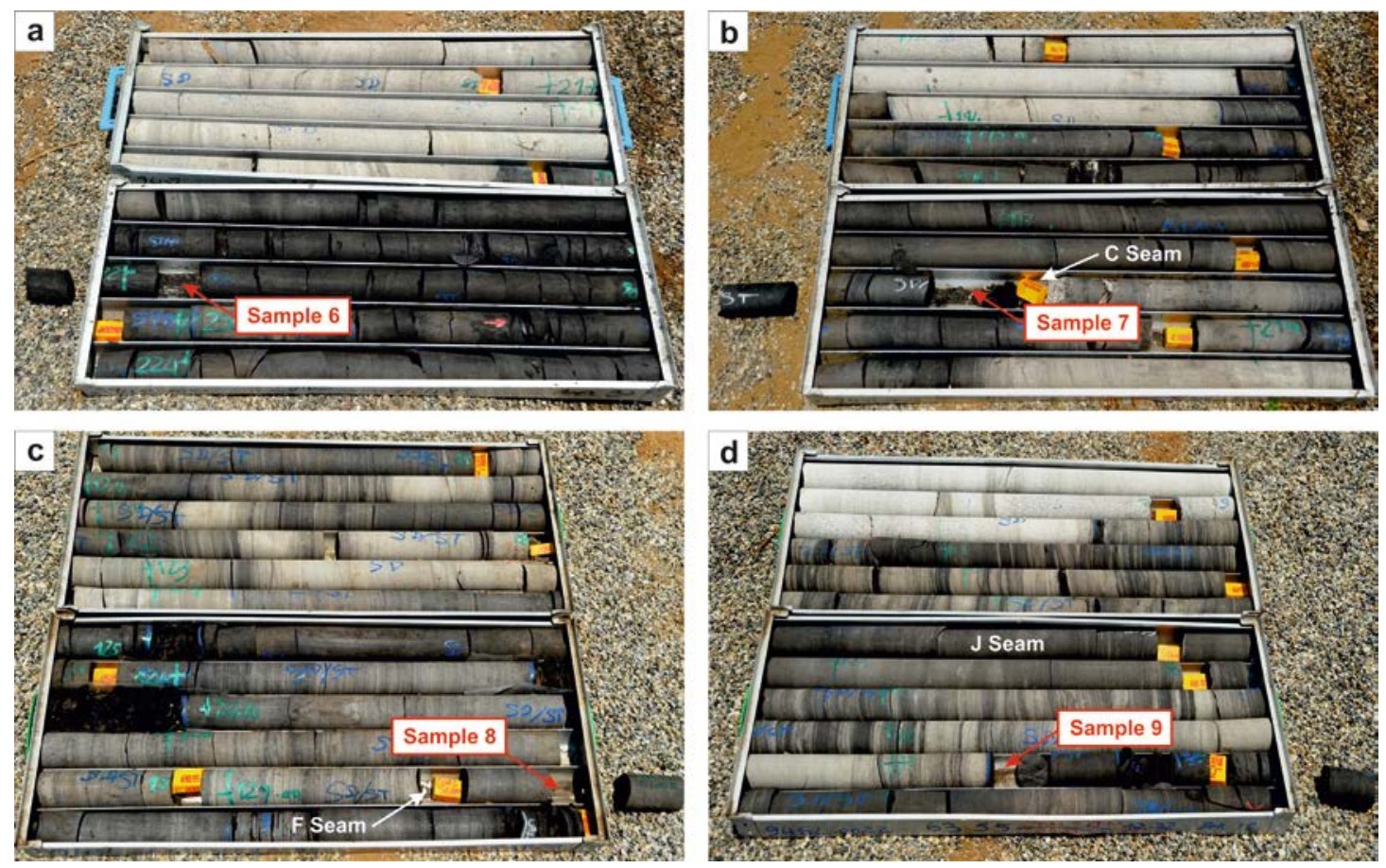

Figure 6 

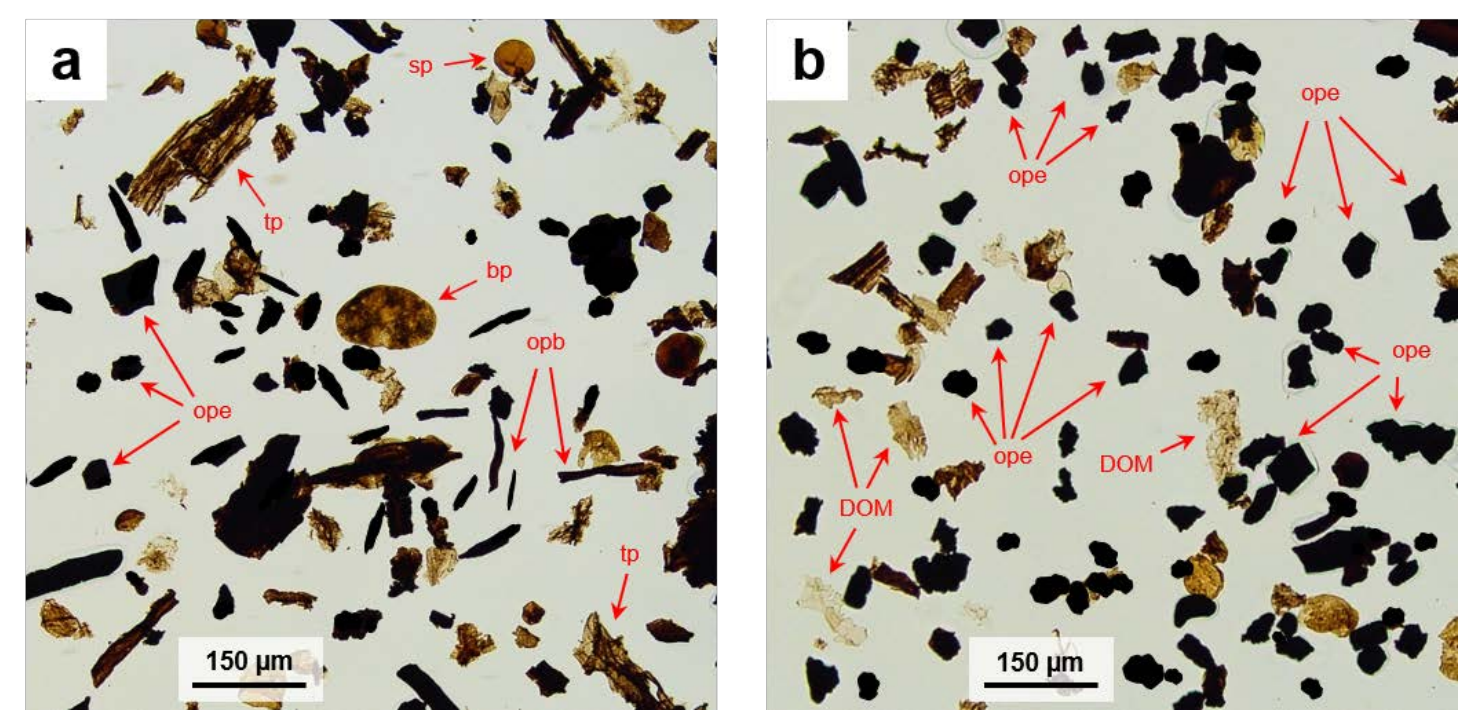

Figure 7

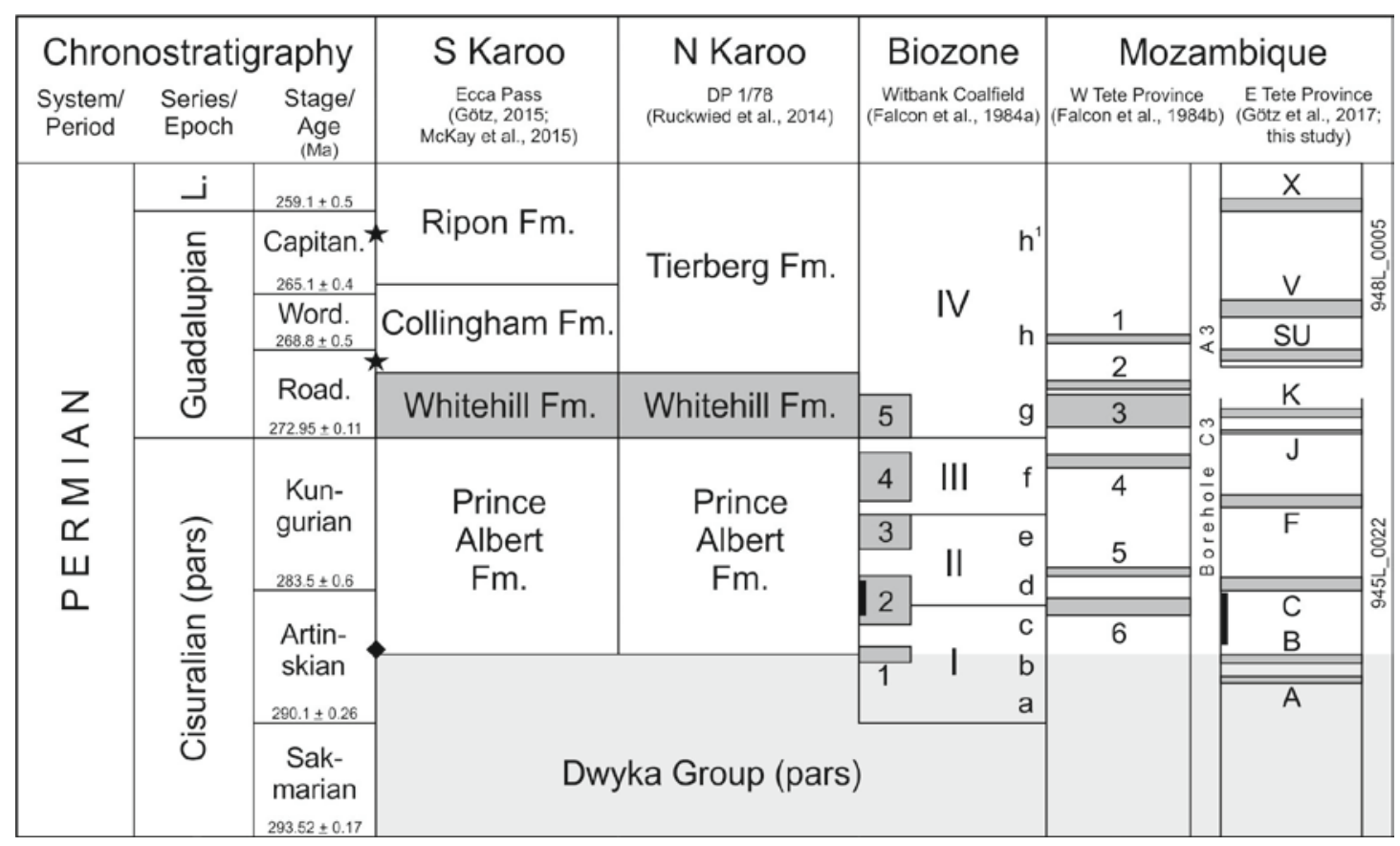

Figure 8 